\title{
PEMBERDAYAAN PEMANDU WISATA LOKAL DI DAYA TARIK WISATA HIDDEN CANYON BEJI GUWANG, SEBAGAI PARIWISATA BERBASIS MASYARAKAT DI KABUPATEN GIANYAR
}

\author{
Putu Ade Wijana \\ Email: wiyana.ade@gmail.com \\ POLITEKNIK INTERNASIONAL BALI
}

\begin{abstract}
Community-Based Tourism (CBT) is an alternative tourism that includes community participation as a major element in the tourism industry. This study aims to determine the empowerment of local tour guides in the tourist attraction of Hidden Canyon Beji Guwang as community-based tourism in Gianyar Regency. This study used a qualitative approach in which data were obtained through observation, interviews, and literature study. The theory used in this research is community empowerment theory and community-based tourism theory. The results obtained are that the manager of Hidden Canyon tourism object Beji Guwang is empowering local tour guides there. The form of empowerment is English language training, security, and safety training, especially in water rescue.
\end{abstract}

Keywords: Local Tour Guide, Community Empowerment, Community Based Tourism

\section{ABSTRAK}

Pariwisata berbasis masyarakat atau Community-Based Tourism (CBT) merupakan salah satu jenis pariwisata alternatif yang memasukkan partisipasi masyarakat sebagai unsur utama dalam pariwisata. Penelitian ini bertujuan untuk mengetahui pemberdayaan Pemandu Wisata Lokal di daya tarik wisata Hidden Canyon Beji Guwang sebagai pariwisata berbasis masyarakat di Kabupaten Gianyar. Penelitian ini menggunakan pendekatan kualitatif dengan menggunakan teknik pengumpulan data seperti observasi, wawancara dan studi kepustakaan. Teori yang digunakan pada penelitian ini adalah teori pemberdayaan masyarakat dan teori pariwisata berbasis masyarakat. Hasil penelitian yang didapatkan adalah Pihak pengelola obyek wisata Hidden Canyon Beji Guwang melakukan pemberdayaan terhadap pemandu wisata lokal yang dimiliki. Bentuk dari pemberdayaan tersebut berupa pelatihan berbahasa Inggris, pelatihan keamanan dan keselamatan khususnya penyelamatan dalam air. 
Kata Kunci: Pemandu Wisata Lokal, Pemberdayaan Masyarakat, Pariwisata Berbasis Masyarakat, Hidden Canyon Beji Guwang

\section{Pendahuluan}

Perkembangan sektor pariwisata di Indonesia saat ini berkembang semakin pesat. Perkembangan sektor pariwisata ini menjanjikan dan memberikan manfaat kepada pihak pemerintah, masyarakat maupun swasta. Pemerintah menyatakan bahwa peran strategis pariwisata dalam perekonomian di suatu negara, diprediksi akan semakin meningkat pada masa mendatang, sehingga sektor pariwisata merupakan lokomotif pembangunan yang menarik semua sektor untuk bergerak maju. Sektor pariwisata merupakan sektor ekonomi unggulan (leading sector of economy) yang memiliki kesetaraan posisi dengan komoditas lain seperti kelapa sawit dan hasil tambang. Selain fungsi pokok sebagai pendulang devisa negara, pariwisata juga menjadi sektor potensial untuk dikembangkan. Melalui Kementerian Sekretariat Negara Republik Indonesia, pemerintah Indonesia telah berkomitmen untuk menjadikan pariwisata sebagai salah satu sektor penggerak ekonomi di tahun 2020. Sektor ini dipandang sebagai sektor yang mampu mendorong dan meningkatkan kegiatan pembangunan, membuka usaha dan lapangan kerja baru, serta meningkatkan pendapatan daerah dan masyarakat apabila dikelola dan dikembangkan secara tepat dan maksimal.

Sektor pariwisata tidak hanya bergantung pada sumber daya alam dan sumber daya sosial budaya, tetapi juga bergantung pada sumber daya manusia (SDM) yang tentunya harus memiliki kualitas dan daya saing yang tinggi. Tingkat kunjungan wisatawan ke suatu destinasi wisata tidak dapat dilepaskan dari peranan SDM, mulai dari pihak pemerintah, pihak penanam modal, pihak pelaku pariwisata serta masyarakat. Masyarakat, yang kemudian disebut dengan masyarakat lokal, memiliki posisi strategis 
dalam suatu destinasi pariwisata. Masyarakat lokal merupakan bagian yang tidak terpisahkan, sehingga dalam pengembangan suatu destinasi pariwisata elemen masyarakat wajib dipertimbangkan. Sebuah tempat atau kawasan dapat dijadikan sebuah destinasi wisata bila memiliki faktor atraksi, aksesibilitas, fasilitas, organisasi, dan pemberdayaan masyarakat. Dalam penelitian ini, pemberdayaan masyarakat dimaknai sebagai pemberdayaan SDM.

Peran masyarakat lokal dalam pengembangan suatu destinasi pariwisata yang berkelanjutan telah mendorong munculnya tren baru dalam dunia pariwisata. Pariwisata berbasis masyarakat atau CommunityBased Tourism (CBT) merupakan salah satu jenis pariwisata alternatif yang memasukkan partisipasi masyarakat sebagai unsur utama dalam pariwisata. Penerimaan, dukungan serta toleransi masyarakat terhadap pariwisata akan berkembang dengan optimal dengan adanya partisipasi masyarakat lokal. Industri pariwisata tidak hanya berupa produk pariwisata namun juga memiliki keterkaitan dengan industri lain termasuk masyarakat lokal.

Pemberdayaan masyarakat lokal sebagai Pemandu Wisata Lokal dapat mendukung keberhasilan pengembangan pariwisata berbasis masyarakat. Pemandu wisata merupakan aktor utama dari kegiatan kepemanduan wisatawan. Pemandu wisata memiliki peran tidak hanya dalam hal memberikan kepuasan kepada wisatawan, namun juga dalam hal menjaga serta memelihara keberlanjutan fungsi suatu objek wisata. Disamping itu, seorang pemandu wisata yang profesional mampu menciptakan citra kawasan wisata (destination image), sehingga seorang pemandu wisata sekaligus berperan sebagai ujung tombak promosi dan pemasaran produk wisata, baik yang berupa produk wisata alam dan budaya maupun produk wisata lainnya seperti akomodasi dan cinderamata. 
Pemandu wisata dapat turut serta membantu mewujudkan pembangunan pariwisata berkelanjutan di satu destinasi pariwisata.

Salah satu objek wisata baru yang terletak di Kabupaten Gianyar adalah objek wisata Hidden Canyon Beji Guwang yang berada di Desa Guwang, Kecamatan Sukawati. Pembangunan objek wisata ini mengusung konsep pembangunan pariwisata berbasis masyarakat. Objek wisata ini memanfaatkan secara optimal sumber daya lingkungan, yakni keindahan alam yang sangat menakjubkan berupa tebing bebatuan yang masih sangat dijaga kesucian dan keasliannya. Namun, pemberdayaan SDM di desa ini dapat dinilai masih sangat kurang. Seorang pemandu wisata tidak hanya dituntut untuk mampu berkomunikasi dengan baik, namun juga mampu memandu dan melayani wisatawan dalam arti yang lebih luas. Kemampuan seorang pemandu wisata dalam kegiatan kepemanduan wisatawan dapat dikembangkan secara optimal melalui pemberdayaan kompetensi individu yang baik. Sehingga, pemberdayaan SDM harus dilakukan secara maksimal guna menghasilkan pemandu wisata lokal yang profesional.

Mewujudkan pembangunan pariwisata berkelanjutan berbasis masyarakat merupakan sebuah tantangan dengan adanya pemberdayaan masyarakat yang sungguh-sungguh dilakukan oleh, dari, dan untuk masyarakat. Pendekatan partisipasif merupakan pendekatan pembangunan pariwisata yang serba sentralistik dan bersifat top down. Berdasarkan uraian latar belakang di atas, penelitian ini akan membahas mengenai pemberdayaan pemandu wisata lokal daya tarik wisata Hidden Canyon Beji Guwang di Desa Guwang, Kecamatan Sukawati, Gianyar, sebagai pariwisata berbasis masyarakat. 


\section{Konsep dan Teori}

Konsep dan teori yang dipilih untuk menjelaskan penelitian ini terangkum sebagai berikut.

\subsection{Pemberdayaan Pemandu Wisata Lokal}

Pemberdayaan adalah suatu cara yang diarahkan oleh suatu organisasi atau komunitas untuk masyarakat berpartisipasi secara langsung (Rusmiyati, 2011: 16). Pemberdayaan adalah proses menyeluruh, suatu proses aktif antara motivator, fasilitator, dan kelompok masyarakat yang perlu diberdayakan melalui peningkatan pengetahuan, keterampilan, pemberian berbagai kemudahan, serta peluang untuk mencapai kesejahteraan (Sabtimarlia;2015: 12-13)

Pemberdayaan masyarakat dimaknai sebagai suatu usaha untuk meningkatkan kompetensi, kemampuan pribadi, kreatifitas, dan kebebasan bertindak setiap individu dari suatu kelompok masyarakat untuk mendapatkan akses terhadap sumber daya, sehingga dapat meningkatkan kapasitasnya dengan cara berpartisipasi dalam mewujudkan kualitas diri dan komunitas (Payne, 1977). Konteks pemberdayaan masyarakat dalam penelitian ini merupakan proses menjadikan masyarakat lokal yang memiliki kapasitas atau kemampuan untuk melakukan sesuatu. Hal ini dikarenakan SDM merupakan unsur pendukung utama dalam proses pembangunan selain sumber daya alam, dan teknologi.

Dalam pembangunan kepariwisataan, masyarakat lokal memiliki kedudukan yang tidak kalah pentingnya sebagai salah satu pemangku kepentingan (stakeholder), selain pihak pemerintah dan industri swasta. Pemberdayaan masyarakat yang berada di suatu daerah yang menjadi destinasi wisata melalui kegiatan usaha kepariwisataan merupakan salah satu model pembangunan pariwisata berkelanjutan (sustainable tourism). Salah satu bentuk partisipasi masyarakat dalam sektor pariwisata adalah menjadi seorang pemandu wisata. 
Mancini (2000) menyatakan bahwa pemandu wisata merupakan ujung tombak (front-line employees) yang bertanggung jawab atas terciptanya citra positif suatu daerah destinasi wisata atau objek wisata. Strategi pemberdayaan masyarakat lokal untuk menjadi seorang pemandu wisata lokal dalam pembangunan pariwisata berkelanjutan dimaksudkan untuk memampukan, memberdayakan, memandirikan, dan mengembangkan potensi masyarakat lokal untuk dapat menjadi soerang pemandu wisata yang profesional dengan melakukan berbagai upaya dan strategi. Berdasarkan penjelasan yang telah diuraikan, seorang pemandu wisata lokal menjadi salah satu ujung tombak pariwisata dan memiliki peran penting di sektor pariwisata yang dituntut memiliki keterampilan, kemampuan, dan kompetensi untuk melaksanakan segala perannya. Pemberdayaan pemandu wisata lokal penting dilakukan untuk mewujudkan pemandu wisata lokal yang memenuhi seluruh syarat dan memiliki keterampilan di bidang kepemanduan wisatawan dengan berbagai strategi dan upaya pemberdayaan.

\subsection{Pariwisata Berbasis Masyarakat}

Pariwisata berbasis masyarakat atau pariwisata pedesaan yang secara global dikenal dengan istilah Community-Based Tourism (CBT) merupakan salah satu bentuk dari pariwisata berkelanjutan (sustainable tourism). Ernawati (2018: 4) menjelaskan bahwa pariwisata berbasis masyarakat merupakan pariwisata alternatif berskala kecil yang menggunakan kebudayaan etnik suatu masyarakat atau lingkungan alam sebagai atraksi wisata bagi wisatawan alternatif yang memiliki ketertarikan khusus.

Pariwisata berbasis masyarakat menekankan masyarakat lokal sebagai pelaku utama dalam perencanaan dan pelaksana kepariwisataan. Pemberdayaan, partisipasi serta pengembangan masyarakat lokal ditekankan dalam jenis pariwisata ini. Partisipasi masyarakat merupakan 
bagian integral dari pembangunan perkelanjutan termasuk pengembangan kepariwisataan. Okazaki (2008) menambahkan bahwa keikutsertaan masyarakat dalam pengelolaan akan memastikan kebutuhan dan kepentingan masyarakat terwakili dalam proyek pengembangan. Dengan kata lain, pendekatan ini akan meningkatkan daya tampung masyarakat (community carrying capacity).

Pariwisata berbasis masyarakat dikembangkan pemerintah sebagai upaya untuk memberdayakan masyarakat lokal. Prinsip dasar pariwisata ini adalah "dari masyarakat, oleh masyarakat dan untuk masyarakat". Murphy (1985) menjelaskan bahwa pariwisata berbasis masyarakat menekankan pada lima karakteristiktik, yaitu; (1) Memanfaatkan gaya hidup etnik, budaya atau lingkungan alam sebagai daya tarik wisata; (2) Melibatkan masyarakat dalam perencanaan dan pengelolaan pariwisata; (3) Konservasi budaya dan alam; (4) Menyasar kepuasan wisatawan karena budaya atau lingkungan alam; serta (5) Meningkatkan status sosial dan ekonomi masyarakat setempat.

Berdasarkan uraian tersebut, dapat disimpulkan bahwa pariwisata berbasis masyarakat sebagai sebuah pariwisata alternatif melalui pendekatan dan pemberdayaan yang melibatkan dan meletakkan masyarakat lokal sebagai pelaku penting dan utama dalam perencanaan, pelaksanaan, pengelolaan, pembangunan, dan pengambilan keputusan yang dapat memengaruhi dan memberi manfaat terhadap kehidupan dan lingkungan.

\subsection{Teori Pemberdayaan Masyarakat}

Permberdayaan masyarakat adalah upaya pemanfaatan dan pengelolaan SDM secara efektif dan efisien untuk memberikan daya (empowerment) atau penguatan (strengthening) kepada masyarakat lokal (Mardikanto, 2014). Sunaryo (2013: 215) mendefinisikan pemberdayaan masyarakat sebagai suatu proses yang tidak hanya mengembangkan 
potensi ekonomi masyarakat yang sedang tidak berdaya, namun juga berusaha untuk meningkatkan harkat dan martabat, serta terpeliharanya tatanan nilai budaya setempat.

Pemberdayaan masyarakat merupakan suatu proses atau cara untuk meningkatkan taraf hidup atau kualitas masyarakat. Melalui suatu kegiatan tertentu, yaitu melakukan kegiatan yang bertujuan meningkatkan kualitas SDM, yang disesuaikan dengan keadaan dan karakteristik di masyarakat itu sendiri (Sabtimarlia, 2015: 16). Pada hakikatknya, upaya pemberdayaan masyarakat selalu dihubungkan dengan karakteristik sasaran sebagai sebuah komunitas yang mempunyai ciri dan latar belakang. Fahrudin (2012: 96) menyatakan bahwa pemberdayaan masyarakat adalah upaya untuk memampukan dan memandirikan masyarakat yang dilakukan dengan berbagai upaya. Adapun upaya yang dapat dilakukan untuk memampukan dan memandirikan masyarakat menurut Fahrudin (2012: 97) adalah sebagai berikut.

1. Enabling, yaitu menciptakan suasana yang memungkinkan potensi masyarakat berkembang. Titik tolaknya adalah pengenalan bahwa setiap masyarakat memiliki potensi yang dapat dikembangkan.

2. Empowering, yaitu meningkatkan kapasitas dengan memperkuat potensi yang dimiliki oleh masyarakat.

3. Protecting, yaitu melindungi kepentingan dengan mengembangkan sistem perlindungan bagi masyarakat yang menjadi subjek pengembangan.

Proses pemberdayaan masyarakat dalam pembangunan pariwisata berkelanjutan lebih mengarah kepada bentuk partisipasi, bukan dalam bentuk mobilisasi. Partisipasi masyarakat berkedudukan sebagai produsen yang ikut serta terlibat dalam proses perencanaan hingga proses evaluasi pembangunan pariwisata. Hal ini dilakukan agar masyarakat merasa ikut memiliki sehingga memiliki kemauan, motivasi, dan rasa tanggung jawab 
yang tinggi. Empat prinsip dalam program pemberdayaan masyarakat menurut Mardikanto (2014: 202) adalah sebagai berikut.

1. Prinsip kesetaraan. Terdapat kesetaraan antara masyarakat dengan lembaga yang melakukan program pemberdayaan masyarakat.

2. Partisipasi. Program pemberdayaan yang dapat menumbuhkan kemandirian masyarakat adalah program yang bersifat partisipatif yang direncanakan, dilaksanakan, diawasi, dan dievaluasi oleh masyarakat.

3. Keswadayaan atau kemandirian. Prinsip keswadayaan yaitu menghargai dan mengedepankan kemampuan masyarakat daipada bantuan pihak lain.

4. Berkelanjutan. Pemberdayaan perlu dirancang secara berkelanjutan, walaupun pada awalnya peran pendamping lebih dominan dibandingkan dengan masyarakat sendiri.

2.4 Teori Pariwisata Berbasis Masyarakat

Pariwisata berbasis masyarakat memiliki kaitan erat dengan adanya keterlibatan yang aktif dari masyarakat lokal dalam pembangunan kepariwisataan yang ada. Dalam hal ini, partisipasi masyarakat lokal dapat dilakukan dalam dua cara yaitu; (1) Partisipasi masyarakat dalam pengambilan keputusan, yang berarti masyarakat lokal memiliki kesempatan untuk menyuarakan harapan, ide, keinginan dan kekhawatirannya dari proses pembangunan pariwisata yang dapat dijadikan masukan dalam proses perencanaan; dan (2) Partisipasi masyarakat lokal dalam pembagian manfaat memiliki pengertian bahwa masyarakat lokal memiliki kesempatan yang sama untuk memperoleh keuntungan finansial dari pariwisata (Timothy \& Boyd, 2003).

Pariwisata berbasis masyarakat merupakan industri pariwisata berskala kecil, yang pembangunannya melibatkan berbagai elemen lokal, seperti pengusaha lokal, organisasi lokal, masyarakat lokal serta 
pemerintah lokal. Jenkins (1982) dalam penelitiannya telah melakukan perbandingan antara pariwisata berskala kecil dengan pariwisata berskala besar. Perbedaan karakteristik kedua jenis industri pariwisata tersebut dapat dilihat berdasarkan Tabel 1 berikut ini.

Tabel 1. Karakteristik Pembangunan Pariwisata Skala Kecil dan Skala Besar

\begin{tabular}{|c|l|l|}
\hline No. & \multicolumn{1}{|c|}{ Skala Kecil } & \multicolumn{1}{c|}{ Skala Besar } \\
\hline 1. & $\begin{array}{l}\text { Secara fisik menyatu dengan struktur } \\
\text { ruang atau kehidupan masyarakat } \\
\text { lokal. }\end{array}$ & $\begin{array}{l}\text { Secara fisik terpisah dari komunitas } \\
\text { lokal, namun efektif membangun citra } \\
\text { kuat dalam rangka promosi. }\end{array}$ \\
\hline 2. & $\begin{array}{l}\text { Perkembangan kawasan wisata } \\
\text { bersifat spontan / tumbuh atas } \\
\text { inisiatif masyarakat lokal } \\
\text { (spontaneous). }\end{array}$ & $\begin{array}{l}\text { Pengembangan Kawasan melalui } \\
\text { perencanaan yang cermat dan } \\
\text { profesional (well planned) } .\end{array}$ \\
\hline 3. & $\begin{array}{l}\text { Partisipasi aktif masyarakat lokal } \\
\text { dalam pembangunan pariwisata. }\end{array}$ & $\begin{array}{l}\text { Investor dengan jaringan internasional } \\
\text { sebagai pelaku utama usaha } \\
\text { kepariwisataan. }\end{array}$ \\
\hline 4. & $\begin{array}{l}\text { Interaksi terbuka dan intensif antara } \\
\text { wisatawan dengan masyarakat lokal. }\end{array}$ & $\begin{array}{l}\text { Interaksi sangat terbatas antara } \\
\text { wisatawan dengan masyarakat lokal. }\end{array}$ \\
\hline
\end{tabular}

Sumber: Jenkins, 1982

Berdasarkan komparasi pada Tabel 1, terlihat perbedaan karakteristik antara pembangunan pariwisata berskala kecil dengan pembangunan berskala besar. Secara fisik, struktur pembangunan berskala kecil menyatu dengan ruang atau kedidupan masyarakat lokal dan masyarakat lokal berpartisipasi secara aktif dalam pembangunan pariwisata, sedangkan pembangunan pariwisata berskala besar pelaku utama usaha adalah investor dengan jaringan internasional. Integrasi masyarakat lokal dalam perencanaan, pembangunan serta pengelolaan destinasi pariwisata berbasis masyarakat merupakan hal yang perlu diperhatikan. Alur pikir integrasi keterlibatan masyarakat lokal dalam perencanaan, pengembangan dan pengelolaan destinasi wisata berbasis masyarakat dapat digambarkan sebagai berikut: 


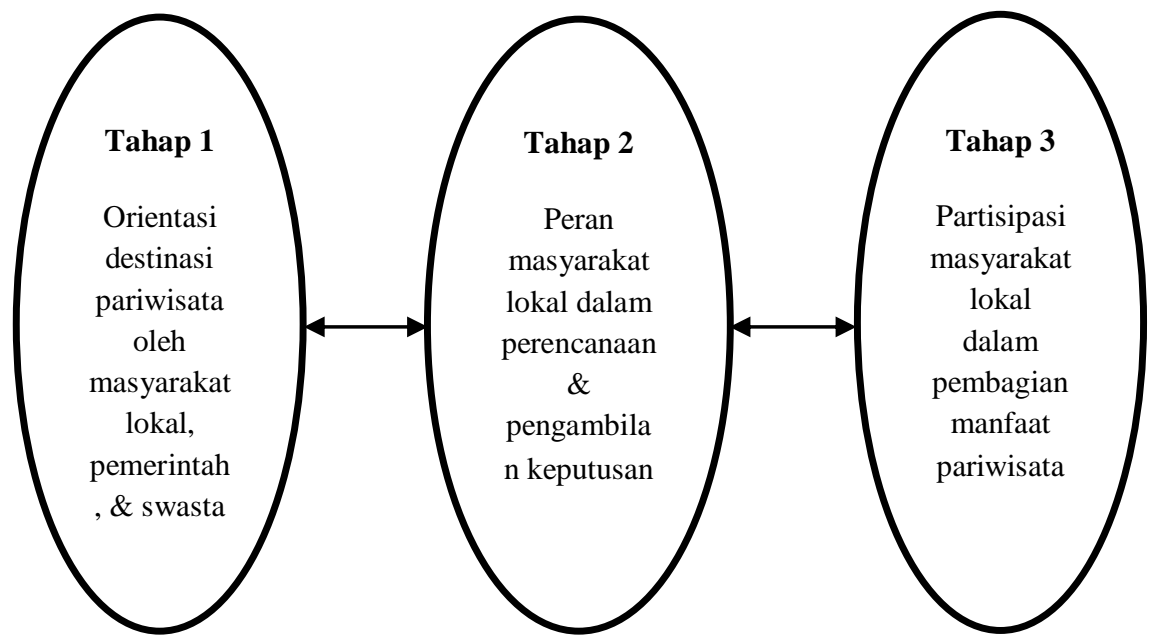

Gambar 1. Integrasi Masyarakat Lokal dalam Perencanaan, Pengembangan dan Pengelolaan Destinasi Pariwisata Berbasis Masyarakat

Sumber: Murphy (1985)

Masyarakat lokal merupakan bagian yang tidak dapat dipisahkan dari suatu destinasi pariwisata. Berdasarkan Gambar 1, pengintegrasian masyarakat lokal dimulai dari tahap paling awal hingga tahap paling akhir. Kerangka pemikiran integrasi dimulai dari pemahaman mendasar mengenai destinasi pariwisata, berupa produk pariwisata, pasar, dan akses wisata yang tersedia. Selain itu, masyarakat lokal merupakan bagian dari produk pariwisata, sehingga peran masyarakat lokal pada dasarnya sangat strategis dalam menentukan keberlanjutan dari pembangunan destinasi pariwisata berbasis masyarakat.

Masyarakat lokal mendapat ruang dan kesempatan untuk berpartisipasi aktif, baik dalam perencanaan, pengambilan keputusan hingga pembagian manfaat. Peran masyarakat lokal sangat penting dikarenakan masyarakat lokal dengan pengetahuan dan kebijakan lokal yang dimiliki akan lebih memahami potensi produk pariwisata yang akan dikembangkan di suatu daerah yang menjadi destinasi wisata dibandingkan dengan masyarakat luar. Masyarakat lokal dilibatkan dalam setiap tahapan, dimulai dari tahap perencanaan, pembangunan, pengelolaan, 
pengembangan, pemantauan hingga tahap evaluasi. Dengan adanya partisipasi masyarakat lokal dalam pengambilan keputusan, diharapkan masyarakat lokal mampu mengidentifikasi berbagai dampak pariwisata dan dapat merumuskan strategi guna mengoptimalkan dampak positif dan meminimalkan dampak negatif yang ditimbulkan dari adanya pembangunan pariwisata.

\section{Metode Penelitian}

Metode penelitian merupakan cara dalam memahami, menganalisis dan menyimpulkan hasil penelitian. Penelitian ini menggunakan pendekatan kualitatif. Terdapat dua jenis data yang digunakan dalam penelitian ini yakni data kualitatif dan data kuantitatif. Teknik pengumpulan data dalam penelitian ini (1) melakukan observasi secara langsung ke lokasi penelitian untuk mendapatkan data secara akurat, (2) wawancara mendalam terhadap informan yang telah ditentukan dengan menggunakan teknik purposive sampling, (3) melakukan studi kepustakaan atau dokumentasi. Data yang dikumpulkan kemudian dianalisis dengan menggunakan (1) reduksi data, (2) penyajian data, dan (3) pengambilan kesimpulan. Data yang dikumpulkan kemudian diolah secara deskriptif dan interpretatif sehingga mendapatkan hasil akhir mengenai pemberdayaan pemandu wisata lokal di daya tarik wisata Hidden Canyon Beji Guwang sebagai pariwisata berbasis masyarakat di Kabupaten Gianyar.

\section{Pemberdayaan Pemandu Wisata Lokal Di Daya Tarik Hidden} Canyon Beji Guwang Sebagai Pariwisata Berbasis Masyarakat di Kabupaten Gianyar.

Pemandu wisata lokal memiliki peranan penting dalam pembangunan pariwisata berbasis masyarakat. Sama seperti keterlibatan 
masyarakat lokal, pemandu wisata lokal juga elemen penting yang harus ada dalam setiap destinasi wisata karena bagaimanapun juga pemandu wisata lokal memiliki pemahaman yang lebih baik tentang destinasi wisata yang di miliki. Pentingnya peranan pemandu wisata lokal sehingga perlu dilakukan pemberdayaan terhadap pemandu lokal tersebut. Pemberdayaan dimaksudkan agar para pemandu lokal memiliki keterampilan cukup pada saat melayani wisatawan yang datang berkunjung. Selain itu, pemberdayaan pemandu wisata lokal juga diperlukan agar para pemandu wisata lokal dapat bersaing secara global.

Hidden Canyon Beji Guwang memiliki visi untuk memberdayakan masyarakat lokal guna mengatasi pengangguran. Proses rekrutmen pemandu wisata lokal di Objek Wisata Hidden Canyon Beji Guwang awalnya tidak berdasarkan kualifikasi dan profesionalisme dikarenakan oleh visi yang mereka miliki guna mengurangi pengangguran di wilayah mereka. Seiring berjalannya waktu keberadaan Objek Wisata Hidden Canyon Beji Guwang semakin dikenal oleh wisatawan lokal maupun wisatawan mancanegara sehingga menyadarkan pihak pengelola bahwa keberadaan pemandu wisata lokal merupakan garda terdepan dalam memberikan pelayanan kepada wisatawan yang berkunjung.

Pihak pengelola menyadari betapa pentingnya peranan dari pemandu wisata lokal sehingga mengadakan pemberdayaan untuk pemandu wisata lokal setidaknya mereka dapat berkomunikasi dengan wisatawan yang berkunjung sehingga para pemandu wisata lokal diberikan pelatihan kursus bahasa inggris. Pemberdayaan pemandu wisata lokal yang diberikan tidak selalu berjalan dengan lancar. Kendala yang dialami oleh pihak pengelola salah satunya berupa kemampuan para pemandu wisata lokal dalam mengikuti pelatihan bahasa inggris yang diberikan oleh pihak pengelola sedikit kurang dikarenakan tamatan akademik mereka hanya sampai pada batas Sekolah Dasar, bahkan beberapa hanya sampai pada 
kelas 3, sehingga hal tersebut sempat menjadi kendala diawal pemberdayaan yang dilakukan oleh pihak pengelola.

Pemberdayaan pemandu wisata lokal memiliki artian penting selain untuk menambah pengetahuan dan skill bagi pemandu tersebut namun juga sebagai keberlanjutan bagi destinasi wisata yang memiliki pemandu wisata lokal di dalamnya. Sehingga sebisa mungkin pihak pengelola seharusnya melakukan pemberdayaan bagi pemandu wisata lokalnya apapun bentuknya. Objek wisata Hidden Canyon Beji Guwang telah melakukan berbagai bentuk pemberdayaan bagi pemandu wisata lokal yang mereka miliki. Hal ini merupakan bentuk dari kepedulian pengelola objek wisata terhadap karyawan mereka.

Pemandu wisata lokal di objek wisata Hidden Canyon Beji Guwang diberikan pelatihan bahasa Inggris oleh pihak pengelola agar dapat berbicara dengan baik kepada wisatawan asing yang datang berkunjung. Pelatihan bahasa Inggris tersebut dilakukan selama 9 bulan dengan melibatkan 3 orang pengajar yang merupakan masyarakat setempat yang merupakan seorang praktisi pariwisata dan 2 orang yang berprofesi sebagai guru bahasa Inggris. Guru terakhir yang memberikan pelatihan menggunakan metode praktik berbicara secara langsung kepada wisatawan, sehingga hal tersebut terbukti dalam meningkatkan kemampuan berbahasa asing mereka. Selama memberikan pelatihan bahasa Inggris kepada pemandu wisata lokal di objek wisata Hidden Canyon Beji Guwang, ketiga pengajar tersebut tidak dibayar oleh pihak pengelola. Mereka memberikan pelatihan secara sukarela demi kemajuan Desa Guwang khususnya bagi objek wisata Hidden Canyon Beji Guwang. Selain aktif dan mampu berbahasa Inggris, pemandu wisata lokal objek wisata Hidden Canyon Beji Guwang kini juga mampu menguasai bahasa Rusia untuk berkomunikasi dengan wisatawan yang datang berkunjung. 
Bentuk pemberdayaan pemandu wisata lokal di objek wisata Hidden Canyon Beji Guwang tidak berhenti pada pelatihan bahasa Inggris. Pemandu wisata lokal tersebut juga dibekali pengetahuan mengenai safety (keamanan) yang harus diberikan kepada wisatawan ketika terjadi sesuatu hal yang tidak diinginkan, mengingat Hidden Canyon Beji Guwang merupakan salah satu daya tarik wisata yang masuk ke dalam wisata minat khusus dan memiliki medan yang cukup berbahaya bagi wisatawan.

Disamping kemampuan bahasa juga dibutuhkan kemampuan bagaimana menyelamatkan Tamu dari tenggelam. Kita bekerjasama dengan BDPBN Gianyar melakukan kursus2 penyelamatan di Air. Juga tidak jarang juga mengalami kecelakaan dalam penelusuran sungai. Para guide lokal sudah dibekali dengan kemamapuan P3K bekerjasama dengan PMI Gianyar

(Hasil wawancara dengan Bapak I Ketut Muda, 12 Juni 2020)

Pihak pengelola objek wisata Hidden Canyon Beji Guwang menjalin kerjasama dengan BDPBN Kabupaten Gianyar dalam memberikan pelatihan dalam melakukan penyelamatan di air karena tidak jarang wisatawan yang mengalami kecelekaan ketika melakukan penelusuran sungai. Pemandu wisata lokal di objek wisatawan dibekali pengetahuan mengenai penanganan pertama yang harus dilakukan ketika terjadi sesuatu dan pemahaman mengenai P3K yang diberikan pelatihan secara langsung oleh PMI Kabupaten Gianyar. Bentuk pemberdayaan ini dilakukan selain untuk menambah pengetahuan pemandu wisata lokal mengenai keamaan untuk wisatawan juga secara tidak langsung memberikan rasa aman bagi wisatawan yang ingin atau sedang berkunjung ke objek wisata Hidden Canyon Beji Guwang karena keamanan wisatawan merupakan satu faktor penting yang tidak boleh dilupakan dan harus mendapat perhatian khusus oleh semua pihak.

Pemberdayaan yang diberikan oleh pihak pengelola terhadap pemandu wisata lokal di objek wisata Hidden Canyon Beji Guwang tidak hanya berbentuk dalam pelatihan namun juga berbentuk insentif. 
Pemberdayaan dalam bentuk insentif ini bertujuan untuk meningkatkan kesejahteraan pemandu wisata lokal di objek wisata Hidden Canyon Beji Guwang. Pemberian insentif berupa service charge sebesar 7\% dari gross income (pendapatan kotor) di samping hak mereka yang berupa guide fee sebesar 26\% dari gross income (pendapatan kotor).

Pemberdayan Dalam hal peningkatan kesejahateraan: kita sebagai pengelola memberikan mereka Service Charge sebesar $7 \%$ dari Gross income. Padahal status Mereka adalah feelensence di samping hak mereka berupa guide fee $26 \%$ dari GI. Mereka juga di cover dg Jamsostek untuk Kematian dan Kecelakaan Kerja dan juga ansurasi kecelakaan dari Jiwa Seraya Putra. Pakian seragam juga kita berikan. Dan Suka Duka untuk Karya dan Keluarganya (Hasil wawancara dengan Bapak I Ketut Muda, 12 Juni 2020)

Pemberian insentif tidak hanya berbentuk upah, namun juga diberikan dalam bentuk jaminan Kesehatan dan kecelakaan kerja dari pihak ketiga. Hal tersebut dilakukan sebagai bentuk rasa peduli pihak pengelola terhadap keselamatan para pemandu wisata lokal di objek wisata Hidden Canyon Beji Guwang dan juga agar pemandu wisata lokal merasa aman selama melakukan pekerjaan mereka. Bentuk kepedulian lainnya juga berupa insentif yang diberikan kepada pekerja pemandu wisata lokal di objek wisata Hidden Canyon Beji Guwang berupa sumbangan uang ketika mereka memiliki upacara agama di keluarganya. Hal itu menunjukkan keseriusan pengelola dalam melakukan pemberdayaan dalam hal meningkatkan kesejahteraan pekerjanya.

Peningkatan sumber daya manusia melalui pemberdayaan yang telah dilakukan oleh pihak pengelola terhadap pemandu wisata lokal telah menunjukkan peningkatan. Para pemandu wisata lokal yang berjumlah 44 orang tersebut kini sudah cukup banyak yang mampu berbahasa Inggris dan Rusia dengan cukup baik dan kesejahteraan mereka yang cukup baik sehingga berdampak pada citra objek wisata Hidden Canyon Beji Guwang yang berhasil mendapat review (ulasan) yang cukup baik diberbagai laman 
penyedia perjalan daring yang telah mengulas banyak destinasi wisata terkemuka seperti tripadvisor dan traveloka.

Faktor pendukung bagi pihak pengelola untuk melakukan pemberdayaan terhadap pemandu wisata lokal di objek wisata Hidden Canyon Beji Guwang itu adalah objek wisata ini dikenal karena memiliki keindahan alam dan lokasi yang sangat strategis serta berada dekat dengan objek wisata lainnya yang ada di Kabupaten Gianyar seperti Pasar Seni Guwang, Bali Zoo dan Pura Batuan sehingga menjadi pemicu bagi pihak pengelola untuk memberdayakan pemandu lokal yang di miliki agar dapat bersaing dengan objek wisata lainnya dan tidak ditinggalkan oleh wisatawan.

Perbedaan visi antara prajuru desa (pengurus desa) terhadap keberadaan objek wisata Hidden Canyon Beji Guwang ini menjadi salah satu faktor penghambat dalam melakukan pemberdayaan selain terkendala oleh faktor lulusan pemandu wisata lokal yang mereka miliki rata-rata hanya sampai pada kelas 3 Sekolah Dasar. Keberadaan objek wisata Hidden Canyon Beji Guwang ini merupakan Badan Usaha Milik Desa dan dikelola oleh BUMDES Desa Guwang namun masih harus tetap membayar retribusi yang berjumlah Rp. 25.000.000 juta per bulan kepada desa adat yang memiliki lahan parkir tersebut. Selain membayar untuk lahan parkir, objek wisata Hidden Canyon Beji Guwang ini harus membayar kompensasi terhadap 20 orang petani yang tanahnya digunakan sebagai jalan sebesar Rp. 350.000 ribu perbulan untuk masing-masing petani.

\section{Simpulan dan Rekomendasi}

Pihak pengelola obyek wisata Hidden Canyon Beji Guwang melakukan pemberdayaan terhadap pemandu wisata lokal yang dimiliki. Adapun bentuk-bentuk dari pemberdayaan tersebut berupa pelatihan 
berbahasa Inggris yang diberikan kepada para pemandu wisata lokal yang ada di obyek wisata Hidden Canyon Beji Guwang agar para pemandu wisata lokal tersebut dapat berbicara dengan baik dan benar kepada wisatawan asing yang datang berkunjung.

Bentuk pemberdayaan selanjutnya adalah pelatihan mengenai keamanan. Pemandu wisata lokal di obyek wisata Hidden Canyon Beji Guwang diberikan pelatihan mengenai keamanan dan dibekali pengetahuan untuk melakukan penyelamatan ketika sesuatu hal buruk yang terjadi khususnya pengetahuan mengenai penyelamatan di dalam air, dalam hal ini pihak pengelola obyek wisata Hidden Canyon Beji Guwang bekerja sama dengan BDPBN Kabupaten Gianyar dan PMI Kabupaten Gianyar dalam membekali pemandu wisata lokal pengetahuan tentang penyelamatan.

Selain berbentuk pelatihan, pemberdayaan yang diberikan pihak pengelola obyek wisata Hidden canyon Beji Guwang terhadap pemandu wisata yang dimiliki berupa pemberdayaan dalam hal kesejahteraan. Bentuk dari pemberdayaan dalam hal kesejahteraan adalah, pemandu wisata lokal yang bekerja di obyek wisata Hidden Canyon Beji Guwang diberikan upah yang merupakan hak dari mereka sebesar $26 \%$ dari total pendapatan kotor. Selain itu, mereka juga diberikan service charge sebesar 7\% dari total pendapatan kotor mereka. Pemandu wisata lokal di obyek wisata Hidden Canyon Beji Guwang juga diberikan bantuan ketika memiliki upacara keagamaan. Keselamatan para pemandu wisata lokal dan wisatawan yang datang berkunjung juga diperhatikan dengan khusus oleh pihak pengelola. Pihak pengelola obyek wisata Hidden Canyon Beji Guwang bekerja sama dengan Jamsostek dan Jiwa Sraya dalam menjamin keselamatan jiwa baik pemandu wisata lokal dan wisatawan yang melakukan kegiatan wisata di obyek wisata Hidden Canyon Beji Guwang. 


\section{Daftar Pustaka}

Ernawati, Ni Made. 2018. Wisatawan ALternatif Mancanegara di Bali. Jurnal Manajemen Pariwisata. Vol 13 No 1

Fahrudin, Adi. 2012. Pemberdayaan, Partisipasi, dan Penguatan Kapasitas Masyarakat. Bandung: Humaniora

Jenkins, C. L. 1982. The Effects of Scale In Tourism Projects In Developing Countries. Annals of Tourism Research. 9: 229-249

Mancini, M. 2000. Conducting tours: A practical guide. South-Western Publishing Co: Cincinnati.

Murphy, P.E. 1985. Tourism: A Community Approach. New York: Metheun . 2013. Tourism: A Community Approach. UK: Routledge

Mardikanto, Totok. 2014. Corporatte Social Responsibility (CSR). Bandung: Alfabeta

Okazaki, Etsuko. 2008. A Community-Based Tourism Model: Its Conception and Use. Journal of Sustainable Tourism, Vol. 16, No. 5, pp. 511-529.

Payne, M. 1997. Modern Social Work Theory. Journal of Research on Social Work Practice. Vol 8 No 6

Rusmiyati, Chatarina. 2011. Pemberdayaan Remaja Putus Sekolah. Yogyakarta: B2P3KS

Sunaryo, B. 2013. Kebijakan Pembangunan Destinasi Pariwisata Konsep dan Aplikasinya di Indonesia. Yogyakarta: Gava Media

Sabtimarlia. 2015. Pemberdayaan Masyarakat melalui Pengelolaan Desa Wisata Sambi di Dusun Sambi, Pakembinangun, Pakem, Sleman, Daerah Istimewa Yogyakarta. Skripsi. Universitas Negeri Yogyakarta

Timothy, Dallen J. dan Boyd, Stephen W. 2003. Heritage Tourism. New Jersey: Prentice Hall.

\section{Profil Penulis}

Putu Ade Wijana, S.S., M.Par. lahir di Satra, 16 Maret 1991. Menamatkan Sarjana Sastra di Sekolah Tinggi Bahasa Asing (STIBA) Saraswati Denpasar pada tahun 2013. Melanjutkan Pendidikan Magister di bidang pariwisata di Pascasarjana Universitas Udayana yang telah diselesaikan pada tahun 2018. Memiliki pengalaman mengajar Industri Pariwisata, Pariwisata Perhotelan, Pariwisata Ekonomi dan Industri Pariwisata MICE. Pengalaman ini membawanya menjadi Dosen D-IV Pengelolaan Konvensi dan Peristiwa di Politeknik Internasional Bali. 
Putu Ade Wijana

94 JOURNEY Volume 3 Nomor 1, Desember 2020 